\title{
An Empirical Analysis of Underpricing and Oversubscription between Venture-Backed IPO and Non-Venture-Backed IPO in Italy
}

\author{
Maurizio Rija ${ }^{1}$ \\ ${ }^{1}$ Department of Business and Law, University of Calabria, Italy \\ Correspondence: Maurizio Rija, Department of Business and Law, University of Calabria, Italy.
}

Received: February 14, 2019

Accepted: March 4, 2019 Online Published: March 28, 2019

doi:10.5539/ibr.v12n4p143

URL: https://doi.org/10.5539/ibr.v12n4p143

\begin{abstract}
Over the years, in order to meet the financial needs of companies, new forms of financing alternative to the traditional banking channel have been developed. These include the institutional investment in risk capital, which is defined by the terms Anglo-Saxon venture capital and private equity. In this empirical analysis, the divestment of the venture capitalist's participation will be emphasized by listing the invested companies in the stock market, a channel not widely used in Italy, but highly desired because of the various benefits it can bring. Analyzing the IPOs that were carried out in Italy on the main list from 2007 to 2017, we will verify what is described in the economic literature, which is that a venture capitalist, by performing a certification role, is able to reduce the information asymmetries presented in the listing process and, as a result, contain underpricing and improve oversubscription. By using the presence of a venture capitalist within the venture capital as the only variable, it has been observed that on average the underpricing and oversubscription of the venture-backed IPOs slightly differentiate from the non-venture-backed IPOs. However, the study carried out shows that this difference, although not significant, turns out to be very interesting.
\end{abstract}

Keywords: venture capital, initial public offering, private equity, underpricing, oversubscription

\section{Introduction}

The ability of the financial system to guarantee adequate financing to companies is a fundamental element for the growth of the overall economic system. The lack of sufficient financial resources can be a factor limiting the functioning of an entire production system. It is such a significant problem in the Italian market since it is mainly composed of small and medium-sized enterprises (SMEs) that often have greater difficulty in accessing various financing sources (Pesic, 2013).

In Italy, the crisis starting in 2007 has made it more difficult for companies to access bank credit, which is the main financing of SMEs. Also, to achieve the capital objectives imposed by the Basel rules, banking institutions have practiced the so-called credit crunch against companies. In fact, today credit lines are granted, with extreme caution, only to those companies which have excellent financial statements and which can boast a good historical performance in their credit relations, while the prospects for growth are often not adequately considered by credit institutions (De Micheli, 2013).

Over the years, to make companies more resistant to the effects of the credit crunch, new forms of alternative financing channel have been developed. Among these, the institutional investment in venture capital of companies is assuming an increasingly important role within the modern financial system. Although still not widely used in Italy, this alternative financing form is analyzed to accentuate various advantages that can be offered to Italian companies.

First of all, the term institutional investment in risk capital means the contribution of financial resources by specialized operators, in the form of participation in the share capital or underwriting of bonds convertible into shares, over a medium-long time period, in unlisted companies with a project and potential for development. However, what makes this type of funding special is the fact that the institutional investor, together with the financial resources, offers his or her own wealth of knowledge and skills (Aifi, 2000).

The institutional investment activity in risk capital is generally defined by the terms Anglo-Saxon venture capital and private equity (Aifi, 2000). Although often used as synonyms, they can be distinguished according to the moment in which the acquisition of capital takes place in the financed company. Venture capital refers to the 
investment in venture capital of absolutely new companies and companies to be started, with high growth prospects, which would hardly be able to find financial means by traditional ways (Peacock \& Cooper, 2000; Stowell, 2010). In the initial phase of the business activity, the entrepreneur or the members are unlikely to be able to immobilize substantial assets for an indefinite period, not tied to pre-established remuneration and subject fully to the business risk. Furthermore, despite the fact that for SMEs, banks continue to be the main interlocutor for SMEs, credit institutions are unlikely to provide credit in the absence of collateral, of which a new created company is rarely available, or personal guarantees provided by third parties, which are also difficult to find because of the high risk involved (Damiani, 2010). The interventions that venture capitalists make in order to finance the start is called early stage financing. Private equity, on the other hand, concerns the investment in risk capital of companies already underway that need capital to consolidate growth and sustain development. In addition to these interventions, called expansion financing, the private equity business is aimed at financing change processes within the company and at restoring corporate crisis situations (Maci, 2001).

The entrepreneur, in requesting this alternative form of financing, will try to identify the investor that best meets the needs of his business. In turn, the venture capitalist, whose goal is to achieve an important capital gain in the medium to long term through the sale of the acquired shares, will not be willing to finance an entrepreneur. Therefore, between the venture capitalist and the entrepreneur there is a mutual selection, in order to best satisfy their respective objectives (Gounopoulos \& Pham, 2016; Kleinschmidt, 2007).

From an information point of view, venture capitalists are disadvantaged compared to companies. This is because, before funding is granted, they do not fully know the projects and the companies to be financed, so they are not always able to evaluate properly the risks and prospects of return associated with them (Davis, 2002). Moreover, once the loan is disbursed, they are unlikely to be able to fully control the work of the entrepreneur (Corigliano, 2001). To overcome the considerable information asymmetries between the two parties, it is important to make a precise choice of the target company to invest in, through a careful process of research, selection, and evaluation of the various investment proposals received. This procedure, common to all types of investment, takes the name of venture capital process and includes several phases that go from identifying a flow of investment proposals (deal flow) to the disinvestment of the shareholding (Gervasoni \& Sattin, 2002). This last phase, the moment of the way out, is extremely delicate because only after the success of the disinvestment, the ultimate goal of the venture capitalist is attained, which is to achieve the maximum possible return (capital gain) from the investment (Cumming, 2010; Povaly, 2007; Megginson, 2004).

In 2017, the main procedures for the investment's divestment were the trade sale (sale of the investment to industrial shareholders) and the buy back (sale of investments to the same entrepreneur and/or management) (Aifi, 2017). The trade sale is the most practiced method by the venture capitalist because, through the sale of the shareholding in another company, it is able to obtain a greater profit (the price paid by the acquiring company is higher than the actual share value) reaching its object of achieving a high capital gain from the sale of the investment. Instead, he could choose to buy back in the event of an unsatisfactory performance, which would make the company unattractive to other potential buyers (Cendrowski, Martin, Petro \& Wadecki, 2008).

In the shareholders' agreements, some repurchase clauses may be included by the entrepreneur or by the management who take action upon the occurrence of certain conditions such as the limited appreciation of shareholding, the low interest of institutional investors in an IPO transaction or of potential industrial buyers in the event of a trade sale, the poor collaboration of the management or the co-investor and, finally, the reduced company performance (Gervasoni \& Sattin, 2002).

In this paper, the most coveted choice for the venture capitalist, or the divestment of the shares through the listing on the stock exchange of the securities of the invested companies through an initial public offering will be analyzed. It is interesting to analyze this method because it can derive advantages for both investor and company. By choosing this method of disinvestment, the investor, especially in the event that his investment is successful, in addition to achieving high returns, could safeguard his reputational capital. However, as regards the invested company, the admission to the official list of stock exchange is a rather complex process that is difficult to access for small businesses, the venture capitalist helps them to be listed and allows them not only to access a new financing channel, but also to change the proprietary and managerial system, relationships with customers, suppliers, employees and with the financial environment in general (Bienz \& Hirsh, 2006).

Finally, to verify whether the sale of shares (total or partial) through this method is an excellent choice, we will consider two indicators that are traditionally determined to verify the success of an IPO transaction, which are underpricing and oversubscription (Ball \& Shivakumar, 2008; Boulton, Smart \& Zutter, 2011). 


\section{The Italian IPOs in the Last Decade and Literature Review}

The Initial Public Offering (IPO) is a public offering of the securities of a company that intends to be listed on a regulated market (Ernst \& Young, 2015). When this operation is organized by companies in which shareholders are institutional investors (private equity and venture capital operators) it is called venture-backed IPOs (Pennacchio, 2013; Intermonte, 2016). In Italy, from 2007 to 2017, a total of 187 initial public offers were made and of these, 32 are venture-backed IPOs (processing data on AIFI and Italian Stock Exchange)

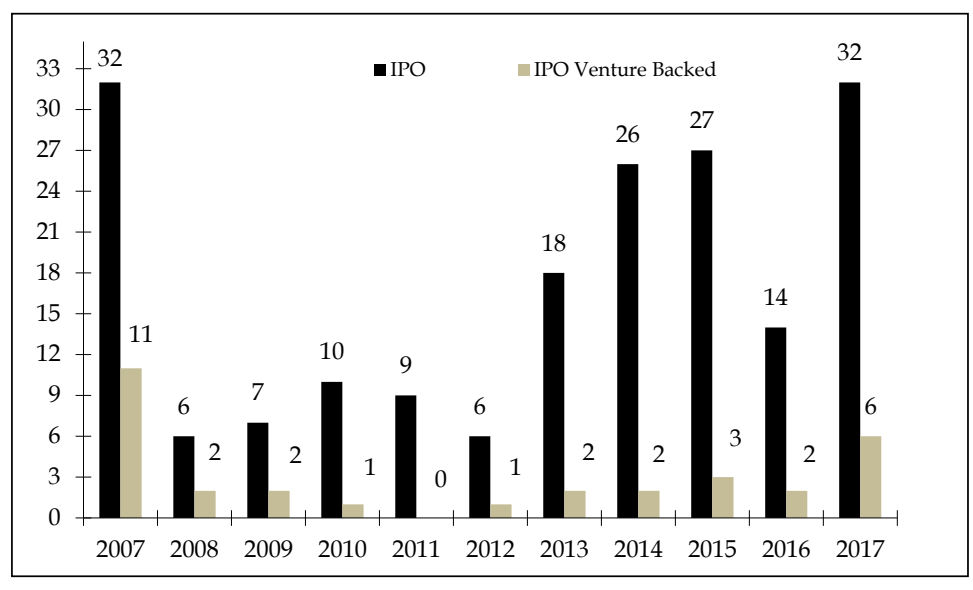

Figure 1. Initial Public Offering in 2007 - 2017

The global crisis, which began in 2008, caused a drastic drop in the number of new stock exchange numbers worldwide and, as a consequence of the limited attractiveness of the markets, the contribution made by private equity and venture capital to the Italian Stock Exchange also suffered a drastic arrest. In particular, in 2011 none of the 9 IPOs was supported by these operators. The IPO market resumed its pace in 2013, which was defined as the record year for new quotations on the Stock Exchange. This increase in companies listed on the Italian market was probably determined by the relaunch, from March 2012, of a single market dedicated to SMEs: AIM Italia. The most significant operation of 2013 concerned a venture-backed IPO, or the listing of Moncler on MTA which was defined as the largest IPO transaction for equivalent required since 2000. Together with Moncler in 2013 and Yoox in 2009, two other significant cases of venture-backed IPO during the period considered were Cerved and Anima, both listed in 2014 (Festa, 2018). 2016 was a difficult year in terms of IPOs, witnessing a reduction of 50\% compared to the previous year. The possible factors determining this reduction may have been Brexit, the presidential elections in the United States and the Italian constitutional referendum that have increased market volatility, especially in the second half of 2016, influencing the strategy of companies and the timing with which to present a possible listing (Peveraro, 2017). On the basis of the new-found confidence in the Italian economy and the growing popularity of the Stock Exchange as an alternative to funding channels, 2017 was an exceptional year for the Italian Stock Exchange as regards the IPO market, which returned to its pre-crisis levels. The number of venture-backed IPOs also increased, representing around 19\% of the total IPOs for 2017.

It is interesting to observe the choice of the stock market on which to place the securities of the invested companies. Even though the Italian AIM for SMEs was established by the Italian Stock Exchange, unfortunately it is not yet considered the main market on which to create the venture-backed IPOs. In fact, from 2007 to 2017 only 7 of the venture-backed IPOs are listed on the Italian AIM, around 22\%. The remaining 25 venture-backed IPOs are listed: 17 on the MTA (53\%) of which 9 in the Star segment and 2 in the Standard segment, 1 on the MTA/MTAX (3\%) in the Blue Chip segment and 7 on the Expandi market (22\%). 


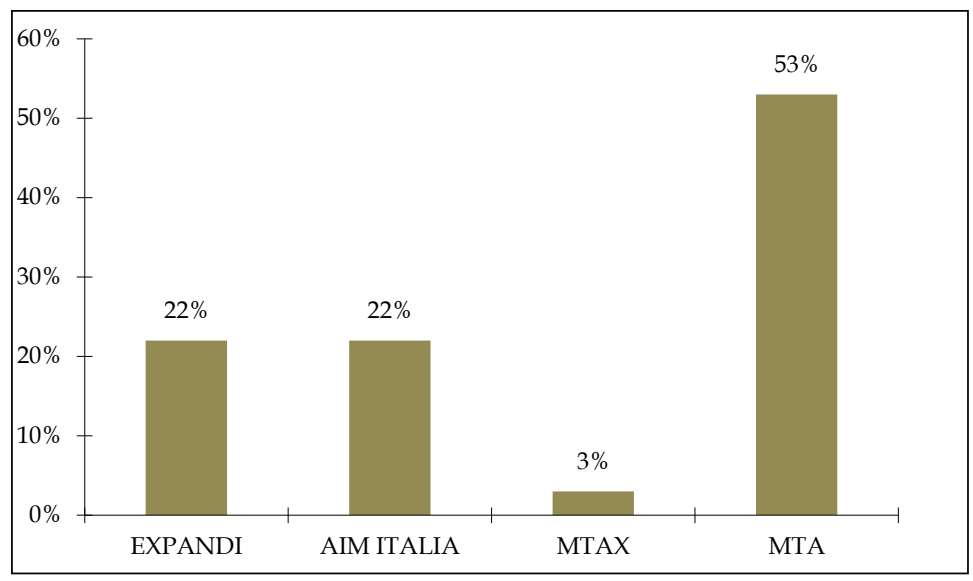

Figure 2. Initial Public Offering venture backed in 2007 - 2017

These results show that the contribution made by private equity and venture capital to the Italian Stock Exchange on the MTA market was not low. This result is probably due to the fact that, in order to be admitted to listing on this market, in addition to the formal requirements, the substantial requirements that venture-backed companies represent are required, thanks to the various services offered by the venture capitalist for the creation of value within the company itself. The contribution of the venture-backed companies, which are committed to meeting the most stringent requirements in terms of transparency and communication, liquidity and corporate governance was also significant within the Star segment of the Italian Stock Exchange. The rules of corporate governance required by the institutional investor in risk capital upon the moment of joining in the company, in order to regulate relations between management and shareholders and to provide the investors with the necessary information and corporate tools to contribute to the development of the company itself, anticipate most of the requirements of the regulations of all the evolved world stock exchanges (Bjuggren \& Mueller, 2009). The invested companies that will want to be listed in the Star segment, therefore, will find an advantage over other companies thanks to this additional tool provided by the investor for the enhancement of the company.

Companies may choose to offer their securities to the public at a lower price, mainly due to the existence of significant information asymmetries among the various parties involved in the placement. The role played by the venture capitalist in the listing process makes it possible to reduce the problem of information asymmetries and, consequently, the phenomenon of underpricing is limited (Gao, Meng, Chan \& Wu, 2017). The economic literature focuses on this aspect.

The first studies develop and test empirically the so-called hypothesis of certification: venture capitalists are well informed on the value of issuers that are presented in the portfolio, therefore, their role is to certify that the issuing price reflects all the internal information available. In this way, the certification of risk capital reduces the information asymmetries that arise in the IPO operations and, consequently, reduce the extent of the underpricing (DuCharme, Malatesta \& Sefcik, 2001; Armstrong, Foster \& Taylor 2009).

In line with the certification hypothesis, various empirical analyzes find that the IPOs of companies that are supported by venture capitalists are cheaper than the other IPOs. The first research on the topic was done in the 90s. The reduction in underpricing is due to the role of certification accomplished by venture capitalists who, operating constantly on the IPO market, are driven by the main intent to consolidate relations with companies, investors and the financial market, because they have reputational capital at stake. A good reputation for competence and honesty will allow him to establish a lasting relationship with the financial market. However, venture capitalists face a trade-off: to maximize the gains from the IPO, allowing the issuer to find more financial resources and increase shareholder profits, and safeguard its reputational capital in front of the financial community. This problem is solved, according to the theory, through an evaluation of the titles that reflects their fundamental value. The institutional investor certifying the fair value of the investee company, helps to bridge the information gap between investors and the company (Megginson \& Weiss, 1991).

The importance of the selection and monitoring activity carried out in the enterprise by the venture capitalist should be underlined, which is reflected in the reduction of the underpricing of the venture-backed IPOs. The presence of the venture capitalist in the pre-IPO phase reduces the risk perceived by investors and certifies the goodness and the potential growth of the invested company compared to the others (Barry, Muscarella, Peavy \& Vetsuypens, 1990). 
A different explanation for the reduction of the underpricing is proposed by another autor who empirically develops and verifies a model that explains the mechanism of formation of the reputation for the venture capitalist. The Author distinguishes between young investors, without a significant track record that have yet to establish themselves on the capital market, and those already established. The results show that younger venture capitalists tend to bring in companies with a higher level of discount to create a reputation. Companies that have become public thanks to their intervention help them establish a good reputation with lenders and raise more money for future investments. Venture capitalists, especially for younger ones where fundraising becomes an important issue, are willing to bear the cost of underpricing to raise as many resources as possible (Gompers, 1996; Fan, 2007).

Over time, different explanations have been formulated. The venture-backed IPOs present higher underpricing levels than the other IPOs during normal periods of activity, while in the periods of stagnation of the stock market, an exactly inverse situation occurs. Observing this regularity, he proposes a theoretical model in which when the IPOs are guided by the initial decision of the investor to liquidate the original investment, in order to finance a new business, the underpricing is reduced. This happens in periods when the availability of new profitable investments is high and venture capital investors, in order to exploit the opportunities, seek to liquidate their investments in companies financed during an IPO quickly. In contrast, in normal times venture capitalists tend to maximize the return of each IPO they have funded (Rossetto, 2008; Gilson, 2003).

\section{Data, Methodology and Hypothesis}

As seen previously, the economic literature focuses on the role played by the venture capitalist in reducing the problem of information asymmetries in the listing process and, consequently, containing the underestimation of securities on international markets (Trester, 1988).

To verify whether this is also the case on the Italian market, a sample of IPOs realized between 2007 and 2017 is considered as the object of study. In particular, initial public offers on the MTA stock market were taken into consideration, which includes not only the companies that were originally listed on this market, but also those that traded on the MTAX market and on the Expandi market (the companies that originally traded on the MTAX market and on the Expandi market were transferred to the main list starting from March 3, 2008, following the merger between MTA and MTAX, and from June 22, 2009, following the final closure of the Expandi market). In the period and for the market, there were 62 new freshmen entering the Stock Exchange, of which 25 incurred by venture capitalists. In addition to underpricing, the oversubscription ratio of the securities of the companies under examination will be determined, being considered an indicator of the success of an IPO transaction.

The distinction between venture-backed IPOs and non-venture-backed IPOs is based on data collected by AIFI (Italian Association of Private Equity and Venture Capital). The data is necessary to determine the underpricing and the oversubscription ratio coming from Italian Stock Exchange S.p.A. and from the Investing.com website.

The underpricing is the difference between the closing price of the first trading day $(\beta)$ and the placement price $(\pi)$, compared to the latter. To facilitate comparison, it will be expressed as a percentage.

$$
\text { Underpricing }=\frac{\beta-\pi}{\pi} * 100
$$

The oversubscription is the ratio between the number of securities required $(\Omega)$ and the number of securities issued by the company listed on the stock exchange $(\alpha)$.

$$
\text { Oversubscription }=\frac{\Omega}{\alpha}
$$

\begin{tabular}{|c|c|c|c|c|c|c|c|}
\hline $\mathbf{N}$. & Company's name & $\begin{array}{c}\text { Placement } \\
\text { price }(€)\end{array}$ & $\begin{array}{c}\text { Price } \\
\text { 1st } \\
\text { day (€) }\end{array}$ & $\begin{array}{c}\text { Titles } \\
\text { offered }\end{array}$ & $\begin{array}{c}\text { Titles } \\
\text { required }\end{array}$ & $\begin{array}{c}\text { Underpricing } \\
(\%)\end{array}$ & $\begin{array}{c}\text { Oversubscription } \\
(\%)\end{array}$ \\
\hline 1 & Anima Holding & 4.2 & 3.837 & $189,626,112$ & $1,049,821,709$ & -8.64 & 5.54 \\
\hline 2 & $\begin{array}{l}\text { Banca } \\
\text { Farmafactoring }\end{array}$ & 4.7 & 4.14 & $53,000,000$ & $88,200,000$ & -11.91 & 1.66 \\
\hline 3 & Banca sistema & 3.75 & 3.91 & $42,876,525$ & $91,022,084$ & 4.26 & 2.12 \\
\hline 4 & Banzai & 6.75 & 6.57 & $8,000,000$ & $13,400,000$ & -2.66 & 1.67 \\
\hline 5 & Bouty Healthcare & 1.3 & 1.4 & $11,200,000$ & $14,571,027$ & 7.69 & 1.3 \\
\hline 6 & Cerved & 5.1 & 5 & $96,000,000$ & $188,262,057$ & -1.96 & 1.96 \\
\hline 7 & Diasorin & 12.25 & 12.55 & $19,000,000$ & $62,785,576$ & 2.44 & 3.3 \\
\hline 8 & Dobank & 9 & 10.25 & $28,500,000$ & $132,494,626$ & 13.88 & 4.65 \\
\hline
\end{tabular}

Table 1. Underpricing and oversubscription of venture-backed IPO 


\begin{tabular}{|c|c|c|c|c|c|c|c|}
\hline 9 & Enervit & 2 & 2.451 & $1,800,000$ & $3,456,000$ & 22.55 & 1.92 \\
\hline 10 & Gamenet & 7.5 & 7.61 & $10,500,000$ & $10,500,000$ & 1.46 & 1 \\
\hline 11 & Group MutuiOnline & 5.6 & 5.973 & $13,829,155$ & $121,051,050$ & 6.66 & 8.75 \\
\hline 12 & IW Bank & 4.6 & 4.9 & $13,385,000$ & $95,630,547$ & 6.52 & 7.14 \\
\hline 13 & Moleskine & 2.3 & 2.28 & $106,360,000$ & $393,532,000$ & -0.86 & 3.7 \\
\hline 14 & Molmed & 2.15 & 1.1885 & $26,100,000$ & $29,300,000$ & -44.72 & 1.12 \\
\hline 15 & Moncler & 10.2 & 14.97 & $76,820,000$ & $2,087,871,624$ & 46.76 & 27.18 \\
\hline 16 & Piquadro & 2.2 & 2.297 & $15,220,000$ & $66,880,000$ & 4.4 & 4.39 \\
\hline 17 & Pramac Group & 4.2 & 4.3 & $10,933,767$ & $41,646,880$ & 2.38 & 3.81 \\
\hline 18 & Prysmian & 15 & 15.89 & $72,000,000$ & $278,756,062$ & 5.93 & 3.87 \\
\hline 19 & RCF Group & 2.8 & 2.8 & $10,000,000$ & $16,715,335$ & 0 & 1.67 \\
\hline 20 & RDB & 5.1 & 5.4 & $13,200,000$ & $34,858,410$ & 5.88 & 2.64 \\
\hline 21 & SAT & 12.35 & 13.31 & $1,860,000$ & $37,952,873$ & 7.77 & 20.4 \\
\hline 22 & Screen Service & 1.6 & 1.7 & $69,250,000$ & $286,325,577$ & 6.25 & 4.13 \\
\hline 23 & Technogym & 3.25 & 3.62 & $57,500,000$ & $216,969,173$ & 11.38 & 3.77 \\
\hline 24 & Unieuro & 11 & 11.5 & $7,000,000$ & $10,000,000$ & 4.54 & 1.43 \\
\hline 25 & Yoox & 4.3 & 4.66 & $24,330,703$ & $105,000,000.00$ & 8.37 & 4.31 \\
\hline
\end{tabular}

Table 2. Underpricing and oversubscription of non venture-backed IPO

\begin{tabular}{|c|c|c|c|c|c|c|c|}
\hline N. & Company's name & $\begin{array}{c}\text { Placement } \\
\text { price }(€)\end{array}$ & $\begin{array}{c}\text { Price } \\
\text { 1st } \\
\text { day (€) }\end{array}$ & $\begin{array}{c}\text { Titles } \\
\text { offered }\end{array}$ & $\begin{array}{c}\text { Titles } \\
\text { required }\end{array}$ & $\begin{array}{c}\text { Underpricing } \\
(\%)\end{array}$ & $\begin{array}{c}\text { Oversubscription } \\
(\%)\end{array}$ \\
\hline 1 & Aeffe & 4.1 & 3.899 & $34,800,000$ & $66,884,781$ & -4.9 & 1.92 \\
\hline 2 & $\begin{array}{l}\text { Aeroporto di } \\
\text { Bologna }\end{array}$ & 4.5 & 5.95 & $14,049,476$ & $39,162,516$ & 32.22 & 2.8 \\
\hline 3 & Aicon Yachts & 4.1 & 4.8 & $35,000,000$ & $180,490,352$ & 17.07 & 5.16 \\
\hline 4 & B\&C Speakers & 5 & 5.1 & $3,600,000$ & $9,507,661$ & 2 & 2.64 \\
\hline 5 & $\begin{array}{l}\text { Best union } \\
\text { company }\end{array}$ & 3.4 & 3.394 & $3,510,000$ & $4,304,823$ & -0.17 & 1.23 \\
\hline 6 & Bialetti Industrie & 2.5 & 2.4816 & $18,750,000$ & $88,790,968$ & -0.736 & 4.74 \\
\hline 7 & Biancamano & 2.8 & 2.977 & $14,000,000$ & $50,431,829$ & 6.32 & 3.6 \\
\hline 8 & Brunelli Cucinelli & 7.75 & 11.6 & $20,400,000$ & $345,000,000$ & 49.67 & 16.91 \\
\hline 9 & Coima Res & 10 & 8.6 & $21,500,000$ & $21,500,000$ & -14 & 1 \\
\hline 10 & Conafi Prestito' & 5 & 5.5017 & $16,500,000$ & $121,239,486$ & 10.034 & 7.35 \\
\hline 11 & Damiani & 4 & 3.664 & $26,355,500$ & $75,105,648$ & -8.4 & 2.85 \\
\hline 12 & $\begin{array}{l}\text { D'Amico } \\
\text { International }\end{array}$ & 3.5 & 3.5 & $59,979,963$ & $164,135,346$ & 0 & 2.74 \\
\hline 13 & Enav & 3.3 & 3.65 & $252,600,000$ & $1,816,209,794$ & 10.6 & 7.19 \\
\hline 14 & Enel green power & 1.6 & 1.6 & $1,415,000,000$ & $1,780,000,000$ & 0 & 1.26 \\
\hline 15 & Enia & 10.1 & 10.87 & $36,463,686$ & $270,827,409$ & 7.62 & 7.43 \\
\hline 16 & Fincantieri & 0.78 & 0.78 & $500,000,000$ & $578,480,000$ & 0 & 1.16 \\
\hline 17 & Finecobank & 3.7 & 4 & $209,166,000$ & $609,079,891$ & 8.1 & 2.91 \\
\hline 18 & Gima TT & 12.5 & 15.3 & $33,800,000$ & $272,200,000$ & 22.4 & 8.05 \\
\hline 19 & Il Sole 24 Ore & 5.75 & 5.6 & $35,091,490$ & $47,764,671$ & -2.6 & 1.36 \\
\hline 20 & Indel B & 23 & 25.98 & $1,600,000$ & $2,108,478$ & 12.95 & 1.32 \\
\hline 21 & Inwit & 3.65 & 4.07 & $239,800,000$ & $1,910,233,884$ & 11.5 & 7.97 \\
\hline 22 & Landi Renzo & 4 & 4.324 & $40,000,000$ & $365,792,163$ & 8.1 & 9.14 \\
\hline 23 & M. Z. Beverage & 11.6 & 11.63 & $12,200,000$ & $18,800,000$ & 0.25 & 1.54 \\
\hline 24 & MaireTecnimont & 2.8 & 2.828 & $96,750,000$ & $152,357,867$ & 1 & 1.57 \\
\hline 25 & Omnia & 5 & 4.7 & $9,000,000$ & $21,660,000$ & -6 & 2.41 \\
\hline 26 & Openjobmetis & 6.6 & 6.82 & $5,750,143$ & $12,280,000$ & 3.33 & 2.14 \\
\hline 27 & OVS & 4.1 & 4.1 & $111,932,000$ & $226,832,292$ & 0 & 2.03 \\
\hline 28 & Pirelli \& C & 6.5 & 6.47 & $400,000,000$ & $824,270,000$ & -0.46 & 2.06 \\
\hline 29 & Poste Italiane & 6.75 & 6.7 & $453,000,000$ & $1,520,000,000$ & -0.74 & 3.35 \\
\hline 30 & Rai Way & 2.95 & 3.088 & $95,000,000$ & $173,733,020$ & 4.67 & 1.83 \\
\hline 31 & Rosss & 2.1 & 2.015 & $1,850,000$ & $1,850,000$ & -4.04 & 1 \\
\hline 32 & $\begin{array}{l}\text { Salvatore } \\
\text { Ferragamo }\end{array}$ & 9 & 9.95 & $38,275,000$ & $78,120,000$ & 10.55 & 2.04 \\
\hline 33 & Servizi Italia & 8.5 & 8.095 & $7,240,000$ & $9,507,661$ & -4.76 & 1.31 \\
\hline 34 & Ternienergia & 1.3 & 1.575 & $4,000,000$ & $6,207,749$ & 21.15 & 1.55 \\
\hline 35 & Tesmec & 0.7 & 0.56 & $58,520,000$ & $61,234,269$ & -20 & 1.05 \\
\hline 36 & Toscana Finanza & 3 & 3.3 & $8,500,000$ & $15,600,455$ & 10 & 1.83 \\
\hline 37 & Zignago Vetro & 4.5 & 4.784 & $13,829,155$ & $121,051,050$ & 6.31 & 8.75 \\
\hline
\end{tabular}

To verify whether there are differences between the companies that are listed thanks to the presence of institutional investors and the companies that are listed without their support, the T-test will be used. The formulated hypotheses are: 
Hip $1 \quad \mathrm{u}_{\mathrm{ivb}}=\mathrm{u}_{\mathrm{invb}}$

there is no significant difference between the underpricing of the venture-backed IPOs and the non-venture-backed IPOs;

$$
\text { Hip } 2 \quad \mathrm{u}_{\mathrm{ivb}} \neq \mathrm{u}_{\text {invb }}
$$

there is a significant difference between the underpricing of the venture-backed IPOs and the non-venture-backed IPOs;

Table 3. Description of statistics of undescription ratio

\begin{tabular}{lcc}
\hline & Venture-Backed IPO & Non Venture-Backed IPO \\
\hline Mean & 3.9348 & 5.109135 \\
Median & 4.54 & 2 \\
Std. Dev. & 14.8818 & 12.45528 \\
Observation & 25 & 37 \\
Test for difference between means & 0 & \\
T Test & -0.233745 & \\
Critical Value T (10\%) & 1.67 & \\
Critical Value T (5\%) & 1.99 & (5)
\end{tabular}

there is no significant difference between the oversubscription of the venture-backed IPO and the non-venture-backed IPO;

Hip $4 \quad$ oivb $\neq$ oinvb

there is a significant difference between oversubscription of venture-backed IPO and non-venture-backed IPO;

Table 4. Description of statistics of oversubscription ratio

\begin{tabular}{lcc}
\hline & Venture-Backed IPO & Non Venture-Backed IPO \\
\hline Mean & 4.9372 & 3.653784 \\
Median & 3.7 & 2.06 \\
Std. Dev. & 6.061751 & 3.36204 \\
Observation & 25 & 37 \\
Test for difference between means & 0 & \\
T Test & 0.727121 & \\
Critical Value T (10\%) & 1.67 & \\
Critical Value T (5\%) & 1.99 & \\
\hline
\end{tabular}

\section{Results and Discussion}

The undervaluation of securities is a common worldwide phenomenon, which distinguishes almost all IPO transactions (Nam, Park \& Arthurs, 2014). Table 1 and 2 show that the underpricing phenomenon is presented in almost all IPOs and only in 18 transactions, underpricing is negative. Regarding the oversubscription ratio, on the other hand, it can be seen as a consequence of the highest underpricing granted to those who purchase the shares. This is an intuitive result, considering that an excess of demand at the time of placement inevitably leads to a portion of the unsatisfied demand, on the first day of listing, in the secondary market, generating an excess of demand and therefore an increase in the price. In confirmation of a possible correlation between the two indicators, the Moncler venture-backed IPO registered an oversubscription of 27 and an underpricing percentage of $46.76 \%$. It was by far the IPO, listed on the main list, which was more successful in the last decade.

Table 3 shows that on average, in the period considered, underpricing is slightly lower for venture-backed IPOs. This result would seem to support the theories stating that in venture-backed IPOs, they reduce the information asymmetries between investors and the issuer, thanks to the certification role played by private equity and venture capital operators. By reducing the information asymmetries that arise in the IPO operation, the increase in a possible underestimation of the securities is also reduced. On the other hand, oversubscription would seem on average to be higher in venture-backed IPOs. This demonstrates the fact that reducing the information asymmetries, new investors, having more information, are more incentivized to acquire the company's securities and also, if they believe that investing in it can be very profitable, also increase the number of securities required. The securities of the venture-backed companies, therefore, are particularly appreciated by the market (Wongsunwai, 2013).

The calculation of the T-tests shows that the difference between the means is not significant. This result would suggest that the IPOs incurred by venture capitalists do not present less asymmetric information and, consequently, both the underpricing and the oversubscription would be on average equal to the other IPOs. 
To demonstrate what the theory illustrates, we try to extend the studied sample (by $61 \%$ ), because the small size of the sample could have determined the inadequacy of the test. Extending, therefore, the sample for a further 4 years (2003-2017) and considering the same stock market, the IPOs examined were 100: 40 venture-backed IPOs and 60 non-venture-backed IPOs. We check whether there is significant difference between the underpricing of the venture-backed and the non-venture-backed IPOs.

Table 5. Description of the statistics of the underpricing ratio of the new sample

\begin{tabular}{lcc}
\hline & Venture-Backed IPO & Non Venture-Backed IPO \\
\hline Mean & 4.2175 & 7.0598 \\
Median & -0.57 & 5.52 \\
Std. Dev. & 12.76455 & 12.19905 \\
Observation & 40 & 60 \\
Test for difference between means & 0 & \\
T Test & 0.7910344 \\
Critical Value T (10\%) & 1.67 & \\
Critical Value T (5\%) & 1.99 & \\
\hline
\end{tabular}

By expanding the sample, we noticed an increase in difference mean in the underpricing, but the significance of the test was not yet reached. The years prior to 2003 were not taken into consideration due to the lack of available data.

Furthermore, not only the presence of the venture capitalist but also different factors contribute to determine the extent of the underpricing. Some of these factors may be the age and track record of the company that people intend to quote, the size of the offer (produced between the number of securities offered and the relative price), the reputation of the underwriter (Cecchini, Jackson \& Liu, 2012). Even when considering the calculation of the oversubscription ratio, some variables have been omitted, such as the sector to which the issuer belongs, its growth rates, the various balance sheet data, the performance of the financial markets, and the historical period.

To overcome the limitations of the study, to verify the existence of a substantial difference between the venture-backed IPOs and the non-venture-backed IPOs in the underpricing that in the oversubscription ratio requires extending the reference sample. Unfortunately, these data are not available and for this reason, further efforts would be needed from an organizational and financial point of view. Furthermore, all the omitted variables could be considered and a regression-based approach should be used.

Although the results achieved do not show that there are significant differences, this study could be used as a starting point for further studies in which the previously indicated limits are overcome.

\section{Acknowledgments}

We would also like to thank the Editors and the anonymous reviewers, whose many invaluable comments improved the substance of the paper.

\section{References}

Aifi \& Pricewaterhousecoopers. (2000). Guida pratica al capitale di rischio. Avviare e sviluppare un'impresa con il venture capital e il private equity. Retrieved from http://www.aifi.it

Aifi. (2017). Dati di mercato anno 2017. Retrieved from http://www.aifi.it

Armstrong, C. S., Foster, G., \& Taylor, D. J. (2009). Earnings management around initial public offerings: a re-examination. Working Paper.

Ball, R., \& Shivakumar, L. (2008). Earnings quality at initial public offerings. Journal of Accounting and Economics, 45, 324-349. https://doi.org/10.1016/j.jacceco.2007.12.001

Barry, C. B., Muscarella, C. J., Peavy, J. W., \& Vetsuypensm M. R. (1990). The role of venture capital in the creation of public companies: evidence from the going-public process. Journal of Financial Economics, 27, 447-471. https://doi.org/10.1016/0304-405X(90)90064-7

Bienz, C., \& Hirsh J. (2006). The dynamics of venture capital contracts, CFS Working Paper, 11.

Bjuggren, P., \& Mueller, D., C. (2009). The modern firm, corporate governance and investment, Cheltenham: Edward Elgar Publishing Limited. https://doi.org/10.4337/9781848449053

Boulton, T. J., Smart, S. B., \& Zutter, C. J. (2011). Earnings quality and international Ipo underpricing. Accounting Review, 86, 483-505. https://doi.org/10.2308/accr.00000018

Cecchini, M., Jackson, S., \& Liu, X. (2012). Do Initial Public Offering firms manage accruals? Evidence from individual accounts. Review of Accounting Studies, 17(1), 22-40. https://doi.org/10.1007/s11142-011-9160-9 
Cendrowski, H., Martin, J. P., Petro, L., \& Wadecki A., (2008). Private equity. History, governance, and operation, Hoboken: John Wiley \& Sons Inc.

Corigliano, R. (2001). Il venture capital. Finanziamento dell'innovazione, capitale di rischio e nuovi mercati finanziari, Rome: Bancaria Editrice.

Cumming, D. (2010). Venture capital: investment strategies, structures, and policies, Hoboken: John Wiley \& Sons Inc. https://doi.org/10.1002/9781118266908

Damiani, E. (2010). Venture capital e private equity. Quaderni della rassegna di diritto civile, Naples: Edizioni Scientifiche Italiane.

Davis, E. P. (2002). Institutional investors and corporate governance, London: Brunel University West London.

De Micheli, A. (2013). Pmi, credit crunch, e capitalizazione. Retrieved from http://www.diritto24.ilsole24ore.com/avvocatoaffari/mercatiimpresa/2013/12/pmi-credit-crunch-e-capitalizz azione.php?uuid=abr6ugc\&refresh_ce=1

DuCharme, L. L., Malatesta, P. H., \& Sefcik, S. E. (2001). Earnings management: Ipo valuation and subsequent performance. Journal of Accounting, Auditing and Finance, 16, 369-396. https://doi.org/10.1177/0148558X0101600409

Ernst \& Young (2015). Ipo il percorso verso la quotazione in borsa. Retrieved from http://www.ey.com

Fan, Q. (2007). Earnings management and ownership retention for initial public offering firms: theory and evidence. Accounting Review, 82, 27-64. https://doi.org/10.2308/accr.2007.82.1.27

Festa, C. (2016). Le Ipo dei private equity battono il mercato, Retrieved from http://www.ilsole24ore.com

Gao, S., Meng, Q., Chan, K. C., \& Wu, W. (2017). Earnings management before IPOs: are institutional investors misled? Journal of Empirical Finance, 42, 90-108. https://doi.org/10.1016/j.jempfin.2017.02.003.

Gervasoni, A. \& Sattin, F. L. (2002). Private equity e venture capital. Milan: Guerrini e Associati.

Gilson, R. (2003). Engineering a venture capital market: lessons from the American experience. Stanford Law Review, 55.

Gompers, P. (1996). Grandstanding in the venture capital industry. Journal of Financial Economics, 42, 133-156. https://doi.org/10.1016/0304-405X(96)00874-4

Gompers, P. (2007). Ownership and control in entrepreneurial firms: an examination of convertible securities in venture capital investments, Harvard Business School Working Paper.

Gounopoulos, D., \& Pham, H. (2016). Credit rating impact on earnings management around initial public offerings. Journal of Business Finance and Accounting, 44(1-2), 154-1965. https://doi.org/10.1111/jbfa.12228

Intermonte. (2016). Le Ipo venture-backed sul mercato italiano, Quaderno di Ricerca, 1, Milan: Politecnico di Milano.

Kleinschmidt, M. (2007). Venture capital, corporate governance, and firm value, Wissenschaft: Gabler Edition.

Maci. G. (2009). Il private equity. Profili operativi ed evoluzione del mercato italiano, Naples: Edizioni Scientifiche Italiane.

Megginson, W. (2004). Towards a global model of venture capital. Journal of Applied Corporate Finance, 16(1). https://doi.org/10.1111/j.1745-6622.2004.tb00599.x

Megginson, W. L., \& Weiss, K. A. (1991). Venture capitalists certification in initial public offerings. The Journal of Finance, 46, 135-151. https://doi.org/10.1111/j.1540-6261.1991.tb03770.x

Nam, D. I., Park, H. D., \& Arthurs, J. D. (2014). Looking attractive until you sell: earnings management, lockup expiration, and venture capitalists. Journal of Management Studies, 51, 1286-1310. https://doi.org/10.1111/joms.12093

Peacock, I. \& Cooper S., (2000). Private equity: implications for financial efficiency and stability, Bank of England Quarterly Bulletin.

Pennacchio, L. (2013). The causal effect of venture capital backing on the underpricing of Italian Ipos, Naples: Università Federico II.

Pesic, V. (2013). Imprenditorialità, capitale di sviluppo e valore, Turin: Giappichelli Editore. 
Peveraro, S. (2017). Crollo delle Ipo nel 2016 nel mondo. Retrieved from http://www.milanofinanza.it

Povaly, S. (2007). Private equity exits. Divestment process management for leveraged buyouts, Berlin: Springer.

Rossetto, S. (2008). The price of rapid exit in venture capital-backed Ipos. Annals of Finance, 4, 29-53. https://doi.org/10.1007/s10436-006-0065-8

Stowell, D. P. (2010). An introduction to investment banks, hedge funds, and private equity, London: Academic Press Elsevier.

Trester, J., (1988). Venture capital contracting under asymmetric information. Journal of Banking and Finance, 22.

Wongsunwai, W. (2013). The effect of external monitoring on accrual-based and real earnings management: evidence from venture-backed initial public offerings. Contemporary Accounting Research, 30(1), 296-324. https://doi.org/10.1111/j.1911-3846.2011.01155.x

\section{Copyrights}

Copyright for this article is retained by the author(s), with first publication rights granted to the journal.

This is an open-access article distributed under the terms and conditions of the Creative Commons Attribution license (http://creativecommons.org/licenses/by/4.0/). 